\title{
The roles of quartz and water in controlling unstable slip in phyllosilicate-rich megathrust fault gouges
}

\author{
Sabine AM den Hartog ${ }^{1,2^{*}}$, Demian M Saffer ${ }^{2}$ and Christopher J Spiers ${ }^{1}$
}

\begin{abstract}
A recent microphysical model for the steady-state frictional behaviour of wet illite/quartz gouges in subduction megathrust settings predicts that velocity-weakening in the seismogenic zone results from a competition between shear-induced dilatation and compaction involving water-assisted, thermally activated deformation (pressure solution) of quartz clasts. While this model is supported by experimental data, proof that quartz and water are a requirement for velocity-weakening is lacking. Here, we report on shearing experiments on water-saturated (near-)pure illite and dry 65/35 illite/quartz gouges, deformed at P-T conditions near those in situ at seismogenic depths along subduction megathrusts. We used low sliding velocities relevant to earthquake nucleation and slow slip events (1 to $100 \mu \mathrm{m} / \mathrm{s}$ ). Previous experiments on wet illite/quartz gouges under the same conditions documented three regimes of slip stability, with velocity-strengthening at $150^{\circ} \mathrm{C}$ to $250^{\circ} \mathrm{C}$ and $400^{\circ} \mathrm{C}$ to $500^{\circ} \mathrm{C}$, and velocity-weakening at $250^{\circ} \mathrm{C}$ to $400^{\circ} \mathrm{C}$. In the present study, wet illite gouge exhibited similar three-regime behaviour, but with velocity-neutral rather than velocity-weakening behaviour at the intermediate temperatures. Dry illite/quartz gouge exhibited near velocity-neutral behaviour at all temperatures investigated. These results confirm that water-assisted, thermally activated quartz deformation is a key process in the velocity-weakening behaviour at intermediate temperatures in wet illite/quartz gouges and support the existing microphysical model. The implication of this model is that seismogenesis occurs under conditions where creep by thermally activated quartz deformation is fast enough to moderate 'brittle' dilatation to remain at subcritical porosity values but too slow to allow ductile shear of clasts.
\end{abstract}

Keywords: Quartz; Water; Pressure solution; Velocity-weakening; Subduction zone seismicity; Illite friction; Brittle-ductile transition

\section{Findings Introduction}

The slip behaviour on subduction zone megathrusts is generally characterized by predominantly aseismic slip in the shallow, up-dip region at temperatures below approximately $150^{\circ} \mathrm{C}$, a seismogenic zone at intermediate depths and temperatures $\left(10\right.$ to $40 \mathrm{~km}$ or $150^{\circ} \mathrm{C}$ to $350^{\circ} \mathrm{C}$ ) where most large interplate earthquakes originate, and aseismic behaviour at greater depths down-dip (e.g. Hyndman et al. 1997). Drilling investigations and studies of exhumed megathrusts indicate that the plate boundary is commonly

\footnotetext{
* Correspondence: s.denhartog@psu.edu

'Department of Earth Sciences, HPT Laboratory, Faculty of Geosciences, Utrecht University, P.O. Box 80.021, 3508 TA Utrecht, The Netherlands 2 Department of Geosciences and Center for Geomechanics, Geofluids, and Geohazards, The Pennsylvania State University, University Park, PA 16802,
} USA

localized within marine (meta)sediments subducted at the trench (e.g. Moore 1989; Saffer et al. 2012; Shipboard Scientific Party 2001, 2003). When these sediments are predominantly pelitic in composition, as is often the case (for example at Nankai or Barbados; e.g. Underwood 2007), it is reasonable to expect that the observed transitions in seismogenic behaviour may be related to changes with depth and/or temperature in the frictional properties of the subducted (meta)pelites.

Temperature-dependent changes in the frictional properties of wet, synthetic gouges with primary compositions similar to metapelites (i.e. mixtures of phyllosilicates and quartz) have indeed been observed in experiments on water-saturated, synthetic 65/35 wt.\% illite/quartz and muscovite/quartz gouges (Den Hartog et al. 2012a, 2013), sheared under in situ megathrust P-T conditions and at 
sliding velocities of 1 to $100 \mu \mathrm{m} / \mathrm{s}$. In the terminology of Rate and State Friction (RSF; Dieterich 1978, 1979; Ruina 1983), both gouges showed stable, 'velocity-strengthening' (or near-neutral) behaviour at low temperatures (Regime 1), potentially unstable, 'velocity-weakening' at intermediate temperatures (Regime 2) and velocity-strengthening at the highest temperatures investigated (Regime 3; Den Hartog et al. 2012a, 2013). For the illite/quartz gouge, velocityweakening (Regime 2) was observed between $250^{\circ} \mathrm{C}$ and $400^{\circ} \mathrm{C}$, whereas for the muscovite/quartz gouge it occurred at $350^{\circ} \mathrm{C}$ to $500^{\circ} \mathrm{C}$. Secondary effects of slip velocity, effective normal stress and pore fluid pressure on the temperature range of velocity-weakening were also observed. These observations offer a possible explanation for the seismogenic zone along subduction megathrusts (Den Hartog et al. 2013), with the velocity-strengthening behaviour at lower and higher temperature mimicking the shallow and deep aseismic zones.

The three regimes of slip stability in these phyllosilicate/ quartz mixtures may be attributed to the temperaturedependent properties of the phyllosilicates, of quartz, of water, or a combination of these. We have shown previously that in the case of wet 65/35 wt.\% muscovite/quartz mixtures, the presence of quartz is essential for velocityweakening, because velocity-weakening is absent in wet pure muscovite (Den Hartog et al. 2013). For 65/35 illite/quartz gouges, the velocity dependence becomes essentially neutral at temperatures up to $350^{\circ} \mathrm{C}$ when deformed dry (i.e. Regimes 1 and 2 cannot be distinguished in the absence of water; Den Hartog and Spiers 2013; Den Hartog et al. 2012a). On the basis of these observations, the three regimes were interpreted to be governed by water-assisted, thermally activated deformation of quartz, in which velocity-weakening is the result of a competition between shear-induced dilatation and compaction involving thermally activated quartz deformation (Den Hartog et al. 2013). A microphysical model was developed for the steady-state frictional behaviour of illite/quartz gouges, incorporating pressure solution as the thermally activated deformation mechanism (Den Hartog and Spiers 2014). This model explains many of the experimental observations on illite/quartz gouges.

Despite the agreement between the model predictions and observations (Den Hartog and Spiers 2014), the key role of water-assisted, thermally activated deformation of quartz in determining the frictional properties of wet illite/ quartz mixtures, notably in causing velocity-weakening, has not yet been confirmed. A decrease in the RSF parameter $(a-b)$ (approaching velocity-weakening behaviour) with increasing quartz fraction in wet illite/quartz mixtures (Den Hartog and Spiers 2013) does suggest such a role. However, the minimum quartz content of the illite/quartz gouges used previously was as high as $35 \mathrm{wt} . \%$. In this paper, we investigate the frictional properties of wet (near-)pure illite samples. In addition, we expand the dataset of Den Hartog et al. (2012a; cf. Den Hartog and Spiers 2013) on the frictional behaviour of dry $65 / 35$ illite/quartz mixtures from $350^{\circ} \mathrm{C}$ to $500^{\circ} \mathrm{C}$, thus including the temperature range of Regime 3 . The new data provides additional experimental evidence supporting our interpretation that velocity-weakening in wet illite/quartz mixtures in Regime 2 is controlled by competition between compaction via water-assisted, thermally activated quartz deformation and dilatation. We argue that the similarity between the velocity-weakening regime in these gouges and the seismogenic zone on megathrusts suggests that seismogenesis may also be caused by this competition.

\section{Material and methods Sample material}

The synthetic fault gouge used in this study consisted of illite-rich Rochester Shale (Folk 1962) or else (near-)pure illite. The Rochester Shale was crushed and sieved to a grain size $<106 \mu \mathrm{m}$ (Ikari et al. 2009b). X-ray diffraction (XRD) analysis showed that the main components of this material are illite (approximately $65 \mathrm{wt} . \%$ ) and quartz (approximately $35 \mathrm{wt} . \%$ ).

The illite was provided by the Institute for Clay \& Interface Mineralogy at RWTH Aachen, (courtesy of Pieter Bertier) and consisted of fine illite/muscovite with 6 to 7 wt.\% quartz and no other detectable clays. Grain size analysis showed that $70 \mathrm{wt} . \%$ of this material had a grain size $<2 \mu \mathrm{m}$. Noting that the structures of illite and very fine muscovite are almost indistinguishable with XRD (cf. Meunier and Velde 2004) and that separation of illite from other mineral phases such as quartz is extremely difficult, we consider this the best approximation to pure illite available.

Ring-shaped samples of both gouges, measuring roughly $1 \mathrm{~mm}$ in thickness and with inner and outer diameters of 22 and $28 \mathrm{~mm}$, were prepared by pre-pressing mixtures of 0.52 to $0.56 \mathrm{~g}$ gouge and about $0.04 \mathrm{~g}$ distilled water. Pressing was done at $170 \mathrm{MPa}$ for $20 \mathrm{~min}$ at room temperature, using a specially designed die. This yielded starting porosities of $12 \%$ to $19 \%$ and $24 \%$ to $28 \%$ for the illite/quartz and pure illite samples, respectively.

\section{Experimental apparatus and procedure}

Rotary shear experiments were performed using the hydrothermal ring shear machine (Additional file 1; for further details, see Niemeijer et al. 2008 and Den Hartog et al. 2012a). In this machine, the sample is sandwiched between two roughened pistons, located in an internally heated pressure vessel filled with distilled water, which forms the pore fluid phase. To inhibit extrusion, the sample is confined between the loading pistons by steel rings. Normal stress is applied to the sample, in excess of the pore fluid pressure $\left(P_{f}\right)$ measured in the vessel, via a 
pressure-compensated upper loading piston, so that the effective normal stress $\left(\sigma_{\mathrm{n}}{ }^{\text {eff }}\right)$ is equal to the axially applied stress (see Den Hartog et al. 2012a). Rotation of the vessel and lower piston allows shearing of the sample at a constant rate, while the shear stress $(\tau)$ generated is measured externally via the non-rotating upper piston.

The experimental procedure followed has been described by Den Hartog et al. (2012b). Rotary shear experiments were performed at an effective normal stress of $170 \mathrm{MPa}$, a pore fluid pressure of $100 \mathrm{MPa}$ or under vacuum (i.e. dry), at temperatures of $200^{\circ} \mathrm{C}$ to $500^{\circ} \mathrm{C}$ and at sliding velocities stepped between 1,10 and $100 \mu \mathrm{m} / \mathrm{s}$. In all experiments, a sliding velocity of $10 \mu \mathrm{m} / \mathrm{s}$ was imposed for the first $5 \mathrm{~mm}$ of shear displacement, before initiating stepwise changes in the velocity (i.e. velocitystepping).

\section{Data processing}

Shear displacement (resolution $\pm 1 \mu \mathrm{m}$ ), axial displacement $( \pm 0.05 \mu \mathrm{m})$, normal force $( \pm 0.05 \mathrm{kN})$ and torque (better than $\pm 6 \mathrm{Nm}$ ) were measured externally and the corresponding signals logged, together with the pore fluid pressure $( \pm 0.005 \mathrm{MPa})$ and temperature $\left( \pm 1^{\circ} \mathrm{C}\right)$ signals, using a 16-bit A/D converter and a logging frequency of 1 to $100 \mathrm{~Hz}$. Shear displacement was corrected for machine distortion, and torque and normal force data for the wet experiments were corrected for seal friction to obtain the shear stress $(\tau)$ and effective normal stress $\left(\sigma_{\mathrm{n}}{ }^{\text {eff }}\right)$ acting on the sample, and the apparent friction coefficient ( $\mu=\tau / \sigma_{\mathrm{n}}{ }^{\text {eff }}$, ignoring cohesion).

The velocity dependence of friction, measured in the velocity-stepping procedure conducted after initial shearing at $10 \mu \mathrm{m} / \mathrm{s}$, was quantified in the framework of the rate and state-dependent friction model (RSF; Dieterich 1978, 1979; Ruina 1983), using the parameter:

$$
(a-b)=\frac{\Delta \mu_{\mathrm{ss}}}{\Delta \ln V}
$$

(e.g. Marone 1998). Here $a$ represents the absolute magnitude of the instantaneous change in apparent friction coefficient $\mu$ upon a step change in sliding velocity from a reference value $V_{0}$, characterized by a steady-state friction coefficient $\mu_{\mathrm{ss}}$, to a new velocity $V$. The parameter $b$ reflects the magnitude of the change in $\mu$ during evolution to a new steady state following the direct effect defined by $a$. The overall change in steady-state friction coefficient is denoted $\Delta \mu_{\mathrm{ss}}$. Positive $(a-b)$ values indicate an increase in steady-state friction coefficient with increasing velocity, i.e. velocity-strengthening, which precludes nucleation of unstable slip, whereas negative $(a-b)$ values signify velocity-weakening and the potential to nucleate unstable slip (e.g. Scholz 1998). Though Equation 1 strictly applies only to steady-state behaviour, many friction experiments generally show some degree of slip hardening (increasing $\mu$ with displacement at constant velocity) due to effects such as gouge extrusion (Den Hartog et al. 2012a). To obtain $\Delta \mu_{\mathrm{ss}}$ and hence ( $\left.a-b\right)$, we detrended the $\mu$ versus displacement curves to remove the background slip hardening effect, as described by Blanpied et al. (1998) and Tembe et al. (2010).

\section{Results}

A list of experimental conditions and key mechanical data is provided in Table 1. For comparative purposes, we first summarize the results of our previous experiments on wet 65/35 illite/quartz mixtures (Den Hartog et al. 2012a; Den Hartog et al. 2012b). This is followed by a description of our present results for the wet illite samples and finally the dry 65/35 illite/quartz samples.

\section{Wet illite/quartz samples}

The evolution of $\mu$ with shear displacement for wet $65 /$ 35 illite/quartz gouge is shown in Figure 1, for representative experiments from Den Hartog et al. (2012a). All experiments showed a rapid increase in $\mu$ until apparent yielding at a displacement of approximately $1 \mathrm{~mm}$ (shear strains $\gamma$ of 1 to 2), followed by a significant slip hardening trend on which the velocity steps are superimposed (Figure 1). In general, higher friction coefficients were measured at higher temperatures (Table 1), characterized by final friction coefficients ranging from 0.68 at $150^{\circ} \mathrm{C}$ to 0.95 at $500^{\circ} \mathrm{C}$. Unstable stick-slip events (Figure 1; Table 1) were occasionally observed at $300^{\circ} \mathrm{C}$ to $400^{\circ} \mathrm{C}$.

For the wet illite/quartz samples, values of $(a-b)$ vary between -0.016 at $350 \mathrm{C}$ and +0.025 at $150^{\circ} \mathrm{C}$ and $500^{\circ} \mathrm{C}$ (Figure 2a). As described previously (Den Hartog et al. 2012a), three slip stability regimes can be identified: predominantly velocity-strengthening $([a-b]>0)$ below $250^{\circ} \mathrm{C}$ (Regime 1$)$, mainly velocity-weakening $([a-b]<0)$ between $250^{\circ} \mathrm{C}$ and $400^{\circ} \mathrm{C}$ (Regime 2), and mainly velocity-strengthening $([a-b]>0)$ above $400^{\circ} \mathrm{C}$ (Regime 3 ). The transitions between these three regimes generally occur at lower temperatures for steps between 1 and $10 \mu \mathrm{m} / \mathrm{s}$ than between 10 and $100 \mu \mathrm{m} / \mathrm{s}$ (Figure 2a).

\section{Wet illite samples}

A representative friction curve for an experiment on wet illite gouge (performed at $500^{\circ} \mathrm{C}$ ) is shown in Figure 1 . As for the wet illite/quartz samples, those for the wet (near-)pure illite samples show slip hardening behaviour and an increase in friction coefficient with increasing temperature (Table 1). The final friction values for the pure illite samples are $14 \%$ to $32 \%$ lower than those for the illite/quartz samples (Table 1). Stick-slip events were occasionally observed at the highest velocities (10 and $100 \mu \mathrm{m} / \mathrm{s}$ ) at $350^{\circ} \mathrm{C}$ and $500^{\circ} \mathrm{C}$ (Table 1 ). 
Table 1 List of experiments, conditions and key data

\begin{tabular}{|c|c|c|c|c|c|c|c|c|c|c|}
\hline Experiment & Material (ill\%/qtz\%) & $\sigma_{\mathrm{n}}{ }^{\text {eff }}(\mathrm{MPa})$ & $T\left({ }^{\circ} \mathrm{C}\right)$ & $P_{f}(\mathrm{MPa})$ & $V(\mu \mathrm{m} / \mathrm{s})$ & Final $\mu$ & Final gouge thickness (mm) & Final shear displacement $(\mathrm{mm})$ & Final $\gamma$ & Stick-slip (Y/N) \\
\hline $\mathrm{RSRS73}^{\mathrm{a}}$ & $65 / 35$ & 170 & 150 & 100 & 10-100-10-1-10-100-10 & 0.68 & 0.62 & 39.9 & 64 & $\mathrm{~N}$ \\
\hline $\mathrm{RSRSO}^{\mathrm{a}}$ & $65 / 35$ & 170 & 200 & 100 & 10-100-10-1-10-100-10 & 0.79 & 0.46 & 49.2 & 49 & $\mathrm{~N}$ \\
\hline RSRS $16^{\mathrm{a}}$ & $65 / 35$ & 170 & 250 & 100 & $10-100-10-1-10-100-10$ & 0.69 & 0.59 & 40.1 & 68 & $\mathrm{~N}$ \\
\hline RSRSO9 ${ }^{\mathrm{a}}$ & $65 / 35$ & 170 & 300 & 100 & $10-100-10-1-10$ & 0.77 & 0.23 & 23.6 & 102 & $Y$, at 1 and $10 \mu \mathrm{m} / \mathrm{s}$ \\
\hline $\operatorname{RSRS38^{\mathrm {a}}}$ & $65 / 35$ & 170 & 350 & 100 & 10-100-10-1-10-100 & 0.81 & 0.64 & 33.9 & 53 & $\mathrm{Y}$, at 10 and $100 \mu \mathrm{m} / \mathrm{s}$ \\
\hline RSRS39 $9^{\mathrm{a}}$ & $65 / 35$ & 170 & 400 & 100 & $10-100-10-1-10-100$ & 0.89 & 0.48 & 35.0 & 73 & $\mathrm{Y}$, at 10 and $100 \mu \mathrm{m} / \mathrm{s}$ \\
\hline RSRS40 ${ }^{a}$ & $65 / 35$ & 170 & 450 & 100 & 10-100-10-1-10-100-10 & 0.91 & 0.52 & 40.6 & 78 & $\mathrm{~N}$ \\
\hline $\operatorname{RSRS43^{\mathrm {a}}}$ & $65 / 35$ & 170 & 500 & 100 & $10-100-10-1-10-100-10$ & 0.95 & 0.66 & 47.5 & 72 & $N^{d}$ \\
\hline RSRS65 $5^{\mathrm{a}}$ & $65 / 35$ & 170 & 200 & Dry & $10-100-10-1-10-100-10$ & $0.75^{\mathrm{b}}$ & 0.68 & 40.2 & 59 & $\mathrm{~N}$ \\
\hline RSRS64 $4^{\mathrm{a}}$ & $65 / 35$ & 170 & 350 & Dry & $10-100-10-1-10-100-10$ & $0.84^{\mathrm{b}}$ & 0.80 & 40.3 & 50 & $\mathrm{~N}$ \\
\hline RSRS66 & $65 / 35$ & 170 & 500 & Dry & $10-100-10-1-10-100$ & $0.74^{c}$ & 0.74 & 30.9 & 42 & $\mathrm{Y}$, at 10 and $100 \mu \mathrm{m} / \mathrm{s}^{\mathrm{d}}$ \\
\hline RSRS86 & $65 / 35$ & 170 & 500 & Dry & $10-100-10-1-10-100$ & $0.51^{c}$ & 0.88 & 26.7 & 11 & $\mathrm{Y}$, at 10 and $100 \mu \mathrm{m} / \mathrm{s}$ \\
\hline RSI1 & $94 / 6$ & 170 & 200 & 100 & 10-100-10-1-10-100-10 & 0.53 & 0.80 & 40.1 & 50 & $\mathrm{~N}$ \\
\hline RSI2 & $94 / 6$ & 170 & 350 & 100 & $10-100-10-1-10-100-10$ & 0.69 & 0.69 & 38.6 & 56 & $\mathrm{Y}$, at 10 and $100 \mu \mathrm{m} / \mathrm{s}$ \\
\hline RSI3 & $94 / 6$ & 170 & 500 & 100 & $10-100-10-1-10-100-10$ & 0.74 & 0.58 & 40.2 & 69 & $\mathrm{Y}$, at $100 \mu \mathrm{m} / \mathrm{s}$ \\
\hline
\end{tabular}

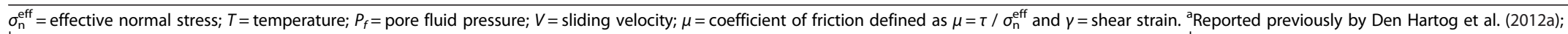

slightly different values than reported in Den Hartog et al. (2012a) due to improved corrections; ' ${ }^{\mathrm{b}}$ these values are affected by vigorous stick-slip behaviour; ${ }^{\mathrm{d}}$ oscillations just after the (apparent) yield point. 


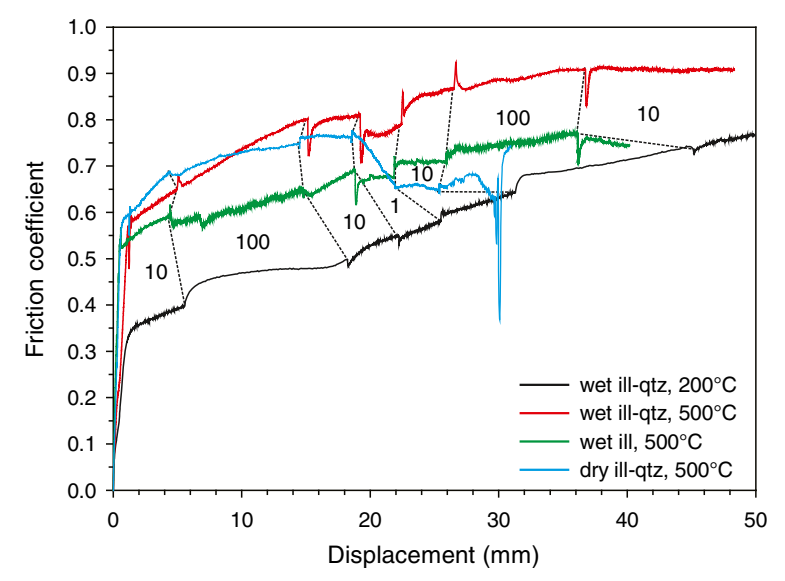

Figure 1 Typical evolution of the coefficient of friction with shear displacement. Results are shown for experiments on wet illite/quartz gouge at $200^{\circ} \mathrm{C}$ and $500^{\circ} \mathrm{C}$ (RSRS07 and RSRS43 respectively; previously reported by Den Hartog et al. 2012a), on pure illite gouge at $500^{\circ} \mathrm{C}(\mathrm{RSI} / 3)$, and on dry illite/quartz gouge at $500^{\circ} \mathrm{C}$ (RSRS66). The applied velocity steps are indicated in micrometre per second $(\mu \mathrm{m} / \mathrm{s})$, with the location of a change in velocity indicated using dashed lines connecting the same velocity step in different experiments. Shear strain $\gamma$ is not indicated on the horizontal axis as it was different for all samples.

For the wet illite samples, values of $(a-b)$ vary between -0.006 and +0.014 (Figure 2b). Although the data is limited, we observe three regimes of velocity dependence as in the wet illite/quartz samples, characterized by more positive values at the lowest $\left(200^{\circ} \mathrm{C}\right)$ and highest $\left(500^{\circ} \mathrm{C}\right)$ temperatures than at the intermediate temperature of $350^{\circ} \mathrm{C}$. However, the data suggest that the three-regime behaviour is less pronounced for the wet illite samples, i.e. the absolute difference between the maximum and minimum value of $(a-b)$ is reduced. In addition, at $350^{\circ} \mathrm{C}$, illite samples show near-neutral to slightly velocity-weakening behaviour, as opposed to mainly velocity-weakening for the illite/quartz mixtures. Furthermore, though the data are few, the threeregime behaviour appears to be displaced to lower temperatures at lower slip velocities (Figure 2b).

\section{Dry illite/quartz samples}

Dry illite/quartz mixtures deformed at $200^{\circ} \mathrm{C}$ and $350^{\circ} \mathrm{C}$ exhibit $24 \%$ to $35 \%$ higher $\mu$ values at yield than the wet illite/quartz mixtures, but lower average strain-hardening rates, resulting in roughly equal final $\mu$ values (within $5 \%$ ). At $500^{\circ} \mathrm{C}$, the dry illite/quartz mixtures are only slightly stronger than the wet one at yield and shows initial slip hardening behaviour followed by slip weakening from approximately 18 to 22 or $27 \mathrm{~mm}$ shear displacement, and vigorous stick-slip events at about 26 to $29 \mathrm{~mm}$ (Figure 1; note that this behaviour was reproduced, cf. Table 1). As in the wet experiments, the dry experiments document increasing $\mu$ with increasing temperature (Table 1), at least up to $18 \mathrm{~mm}$ shear displacement.
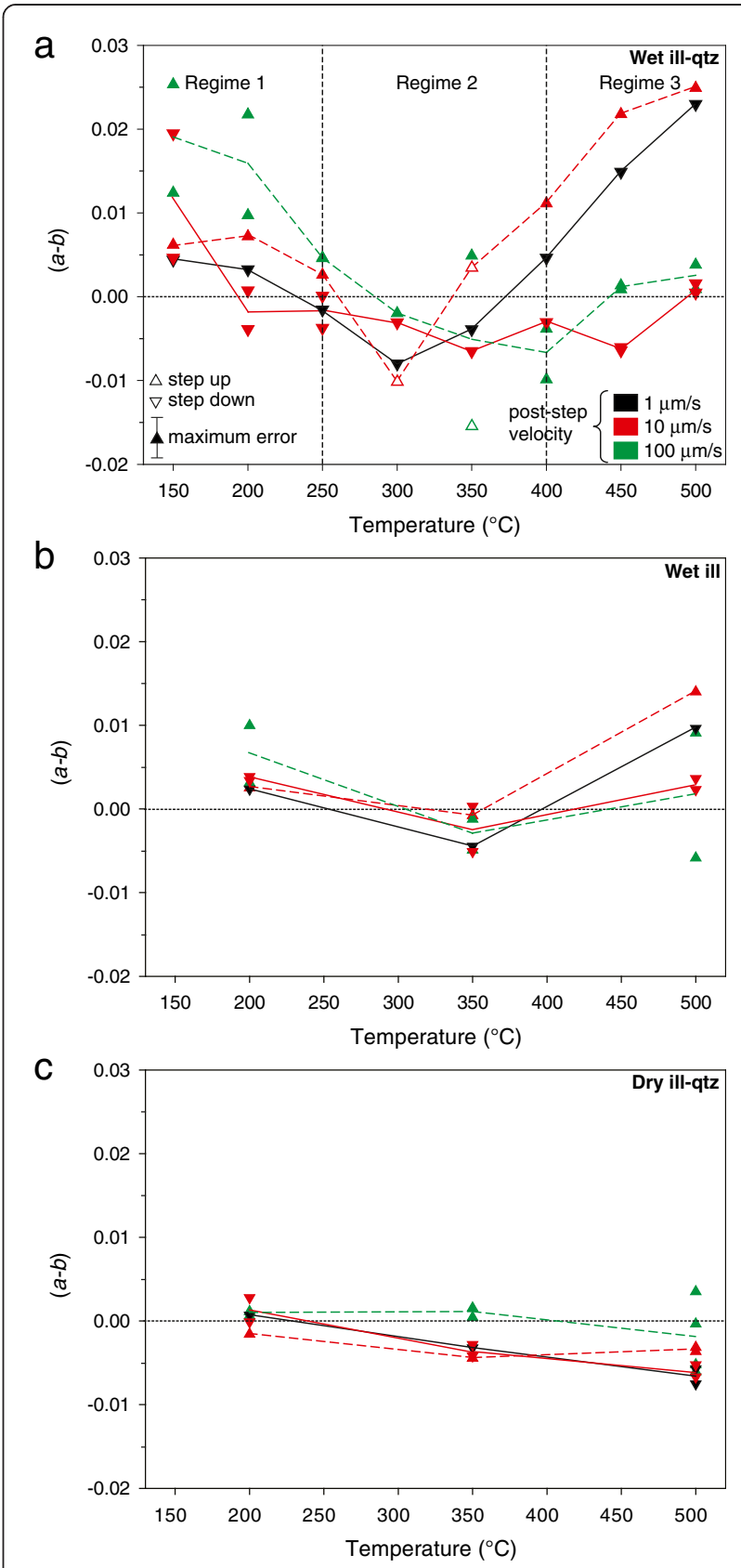

Figure 2 Values of the velocity dependence parameter $(a-b)$ as a function of temperature. Colours indicate the magnitude of the post-step velocity imposed in performing each upward or downward velocity step, as shown in (a). Solid tie-lines designate a step down in velocity, while dashed lines designate a step up. Errors in $(a-b)$ are estimated to lie within \pm 0.0024 (see error bar in the upper plot). (a) Results for wet illite/quartz gouges, previously reported by Den Hartog et al. (2012a). Open symbols are calculated using peak friction values of stick-slip events and differ from the $(a-b)$ values for stick-slip events originally reported by Den Hartog et al. (2012a; Den Hartog and Spiers 2013), which were based on mean friction values. (b) Results for wet (near-)pure illite gouge. (c) Results for dry illite/quartz (see also Den Hartog et al. 2012a). 
At the temperatures investigated, the dry illite/quartz mixtures (Figure 2c) exhibit overall velocity-neutral behaviour with $(a-b)$ varying between -0.004 and +0.004 , but reaching small negative values as low as -0.008 at $500^{\circ} \mathrm{C}$. No three-regime behaviour is apparent from these experiments. Except at $200^{\circ} \mathrm{C}$, the $(a-b)$ values obtained for a post-step velocity of 1 or $10 \mu \mathrm{m} / \mathrm{s}$ are lower than those for higher velocities.

\section{Discussion}

Here, we focus our discussion on slip stability and deformation mechanisms in illite or phyllosilicate/quartz gouges, noting that a detailed comparison of the strength of the wet illite/quartz gouges to other studies (e.g. Moore et al. 1989) has been addressed by Den Hartog et al. (2012a; 2012b). Overall, the frictional strength we report for wet illite/quartz gouge is in good agreement with previous work. Our results for dry illite/quartz mixtures and wet illite, when compared to the data for wet illite/quartz gouges, are consistent with the widely reported weakening effects of both water (e.g. Morrow et al. 2000) and clay content (Tembe et al. 2010).

\section{Role of illite versus quartz in controlling slip stability}

Both the wet illite/quartz and wet illite gouges showed three regimes of velocity dependence, characterised by more positive $(a-b)$ values at low $\left(<250^{\circ} \mathrm{C}\right)$ and high $\left(>400^{\circ} \mathrm{C}\right)$ temperatures than at intermediate temperatures $\left(350^{\circ} \mathrm{C}\right)$, although our data suggest that the threeregime behaviour is muted in the wet illite gouge relative to the wet mixtures (cf. Figure 2a,b). Notably, whereas the wet illite/quartz samples showed predominantly velocity-weakening behaviour in Regime 2, the wet illite samples were velocity-neutral to slightly velocityweakening at $350^{\circ} \mathrm{C}$. Though these observations should ideally be complemented by experiments on wet illite at temperatures intermediate to those investigated here, they are consistent with those previously reported for both wet muscovite/quartz and wet $100 \%$ pure muscovite samples (Den Hartog et al. 2013). Particularly, both wet muscovite/ quartz and wet muscovite gouges showed temperaturedependent three-regime behaviour, but the first exhibited velocity-weakening at $350^{\circ} \mathrm{C}$ to $500^{\circ} \mathrm{C}$, whereas the latter was predominantly velocity-strengthening to neutral.

The difference in the extent of velocity-weakening of wet illite gouge with $6 \%$ to $7 \%$ quartz versus wet $65 / 35$ illite/ quartz gouges, at least at $350^{\circ} \mathrm{C}$, suggests that an increase in quartz content promotes velocity-weakening behaviour. This result supports the proposed key role of quartz in generating velocity-weakening behaviour in wet mixtures of illite and quartz (Den Hartog and Spiers 2014). We attribute the small degree of velocity-weakening in the wet illite gouge to the presence of minor amounts of quartz, possibly accompanied by localization of deformation in parts of the layer where quartz is concentrated (e.g. as noted by streaking of quartz parallel to foliation as reported by Den Hartog et al. (2013)). Such an interpretation is supported by observations of stick-slip events in muscovite gouge with $<10 \%$ quartz, at $400^{\circ} \mathrm{C}$ to $500^{\circ} \mathrm{C}$ (Van Diggelen et al. 2010) or $600^{\circ} \mathrm{C}$ (Mariani et al. 2006), versus velocity-strengthening to neutral behaviour observed in wet pure muscovite gouges (Den Hartog et al. 2013). Complete removal of quartz from illite/quartz mixtures is extremely difficult and, to our knowledge, has thus far not been accomplished.

The inferred key role of quartz in causing velocityweakening in illite/quartz or, more generally, phyllosilicate/quartz gouges, is also consistent with the widely reported velocity-strengthening nature of phyllosilicates, at least at room temperature (e.g. Ikari and Saffer 2011; Moore and Lockner 2008). It also agrees with observations on wet pure quartz, deformed under similar experimental conditions to those that we explored (Chester and Higgs 1992), and exhibiting velocity-weakening at $300^{\circ} \mathrm{C}$.

\section{Role of water in controlling slip stability}

Comparison of data for wet versus dry illite/quartz mixtures (Figure 2a,c) shows that the three regimes of velocity dependence are only present when the mixture is sheared under wet conditions, though additional dry experiments at a range of temperatures are needed to verify this hypothesis. If true, the implication is that the temperaturedependent slip stability of illite/quartz mixtures, and presumably of phyllosilicates and phyllosilicate/quartz mixtures in general, is caused by water-assisted processes: water leads to increased velocity-strengthening at low $\left(<250^{\circ} \mathrm{C}\right)$ and high $\left(>400^{\circ} \mathrm{C}\right)$ temperatures, and to decreased velocity-strengthening (or velocity-weakening when quartz is present) at intermediate temperatures.

The slightly negative $(a-b)$ values obtained for the two experiments on dry illite/quartz performed at $500^{\circ} \mathrm{C}$ (Figure 2c) are not fully consistent with the inferred role of water in producing temperature-dependent slip stability behaviour. However, the friction curves obtained under dry conditions at $500^{\circ} \mathrm{C}$ (cf. Figure 1) show a different shape than all other curves, being characterised by a decrease in the friction coefficient at displacements above $18 \mathrm{~mm}$. The drop in $\mu$ for these experiments could be related to structural or chemical changes of illite at temperatures around $500^{\circ} \mathrm{C}$ under dry conditions, such as decomposition by dehydroxylation (Gualtieri and Ferrari 2006). The result of thermogravimetric analysis (TGA) of the illite/quartz gouge after dry deformation at $500^{\circ} \mathrm{C}$ indeed was slightly different from that of the starting material. Comparison of the XRD patterns before and after deformation at $500^{\circ} \mathrm{C}$, however, revealed no significant difference. The nature of the changes of illite during the dry experiments at $500^{\circ} \mathrm{C}$ could therefore not be determined. Nonetheless, the possible occurrence of modifications of 
illite implies that the $(a-b)$ data of dry illite/quartz gouge at $500^{\circ} \mathrm{C}$ should be interpreted with care.

\section{Microphysical mechanisms}

From the above, it seems likely that (i) water is needed for three temperature-dependent slip stability regimes in illite/quartz gouges and (ii) quartz is needed for velocity-weakening at intermediate temperatures (Regime 2). We tentatively conclude that the transitions from velocity-strengthening at low temperature, to velocity-weakening at intermediate temperatures, and back to velocity-strengthening at high temperature critically depends on water-assisted, thermally activated quartz deformation, for example pressure solution or stress corrosion cracking (cf. Den Hartog et al. 2012a).

Alternative explanations for the frictional characteristics of wet illite/quartz gouges at the conditions explored here are not likely (cf. Den Hartog et al. 2012a). For example, temperature-dependent changes in water properties around the critical point $\left(374^{\circ} \mathrm{C}\right)$ cannot explain the three-regime behaviour, because the sharp changes in the properties of water (e.g. density, solute-bearing capacity) around the critical point are absent at the fluid pressure of the experiments (100 MPa; Lemmon et al. 2010; Wagner and Pruss 2002). The observed velocity dependence of the transition temperature from Regime 2 to Regime 3 for wet illite/ quartz mixtures also makes such an explanation unlikely. Similarly, changes in the mineralogy or phyllosilicate structure are also improbable, since XRD patterns for samples prior to and after deformation at different temperatures closely resembled each other and the interlayer spacing of phyllosilicates showed no consistent change with temperature (Den Hartog et al. 2012a). The onset of crystal plasticity at temperatures above about $350^{\circ} \mathrm{C}$ is sometimes invoked to explain increases in $(a-b)$ with temperature in granite, gabbro and quartz gouges, leading to a transition from velocity-weakening to strengthening (Scholz 1998). However, the data of Hirth and Tullis (1994) and Rutter and Brodie (2004) suggest negligible plastic flow in quartz at the conditions of our experiments, rendering this explanation also unlikely.

The inferred importance of water-assisted, thermally activated quartz deformation is consistent with the quantitative microphysical model for the steady-state frictional behaviour of illite/quartz fault gouge developed recently by Den Hartog and Spiers (2014). The model assumes a foliated, phyllosilicate-supported microstructure which shears by rate-independent frictional slip on aligned phyllosilicates, plus thermally activated deformation of the intervening quartz clasts. At low slip rates or high temperatures, deformation of the clasts accommodates slip on the foliation without dilatation. With increasing velocity or decreasing temperature, shear of the clasts becomes more difficult, increasing bulk shear strength, until slip is activated on inclined portions of the phyllosilicate foliation, where it anastomoses around the clasts. Slip on the anastomosing foliation leads to dilation involving clast/matrix debonding, which is balanced, at steady state, by compaction through thermally activated clast deformation. As the sliding velocity is increased further (or the temperature decreased), an increasing tendency for dilation will lead to an increase in steady-state porosity and a decrease in shear strength until a limiting or critical state porosity is reached (cf. Niemeijer and Spiers 2007). When including pressure solution as the thermally activated process, this model explains many of the main experimental observations on illite/ quartz gouges (Den Hartog et al. 2012a; Den Hartog and Spiers 2014). To date, no existing microphysical model explains the temperature-dependent, three-regime behaviour of pure phyllosilicates. Den Hartog et al. (2013) suggested that this may be governed by a similar competition between multiple mechanisms, including (at least) one that is waterassisted and thermally activated.

\section{Implications for subduction megathrust seismogenesis}

Our new results provide additional data supporting the inferred key role of water-assisted, thermally activated quartz deformation in the frictional behaviour of phyllosilicate/ quartz gouges, as incorporated in the microphysical model summarized above. Because the composition of our illite/ quartz gouge is similar to that of the protolith sediment at many subduction margins (e.g. Steurer and Underwood 2003; Underwood and Deng 1997), the temperaturedependent frictional behaviour described here is directly relevant to understanding temperature- and depth-dependent transitions in slip stability along subduction megathrusts.

The three-regime behaviour observed in experiments on wet illite/quartz mixtures and predicted by the microphysical model (cf. Den Hartog and Spiers 2014) corresponds well with the observations along subduction megathrusts. This suggests that earthquake nucleation along megathrusts may be caused by the same mechanism that results in velocity-weakening behaviour in the model, and that seismogenesis is in fact controlled by gouge compaction through thermally activated deformation of quartz clasts, most likely by pressure solution, that moderates dilatation. We posit that, at the conditions of the seismogenic zone, pressure solution is fast enough to cause compaction that limits the amount of dilatation that can occur at a given slip velocity, keeping the porosity to values below the critical state porosity and leading to essentially brittle behaviour. At higher temperatures, shear is accommodated by pressure solution without dilation, resulting in essentially ductile deformation. In this sense, seismogenic behaviour along megathrusts can be viewed as a brittleductile transition. This interpretation is equally applicable for illite- and muscovite-rich gouges, which both exhibit 
the three-regime behaviour (Den Hartog et al. 2013). Note that although this seems a viable interpretation of the mechanisms controlling the stability changes along a megathrust, it does not exclude other processes, such as a transition to crystal plastic behaviour at the down-dip seismogenic limit (cf. Scholz 1998).

Finally, we note that the velocity dependence of the transition from Regime 1 to Regime 2 for both wet illite/ quartz gouge and wet illite gouge (Figure 2a,b) suggest that values of $(a-b)$ in the lowest temperature regime (Regime 1; $<250^{\circ} \mathrm{C}$ ) are negative at sliding velocities below those explored here $(<1 \mu \mathrm{m} / \mathrm{s})$, but become increasingly positive at the (higher) velocities employed in our experiments. This would imply that at temperatures below roughly $250^{\circ} \mathrm{C}$, and the pressure conditions explored here, nucleation of slip at low velocities is possible, but arrests before a dynamic rupture event can develop. Hence, these properties seem favourable for slow slip behaviour (cf. Ikari and Saffer 2011; Ikari et al. 2009a). Slow slip at depths shallower than the seismogenic zone has indeed been observed, for example at the Nankai Trough (Ito and Obara 2006).

\section{Conclusions}

This study has investigated the effects of quartz and pore water on the frictional behaviour of wet, simulated illite/ quartz gouges. This was approached by performing rotary shear friction experiments on wet (near-)pure illite gouges and on dry 65/35 illite/quartz samples and comparing the results with previous experiments on wet, simulated 65/35 illite/quartz gouges (Den Hartog et al. 2012a), all performed at near in situ megathrust conditions, i.e. an effective normal stress of $170 \mathrm{MPa}$, a pore fluid pressure of $100 \mathrm{MPa}$ or vacuum when dry, at temperatures in the range $200^{\circ} \mathrm{C}$ to $500^{\circ} \mathrm{C}$ and at sliding velocities of 1 to $100 \mu \mathrm{m} / \mathrm{s}$. Our conclusions are as follows:

1. Wet (near-)pure illite gouge shows similar temperature-dependent three-regime slip stability behaviour to that previously found for wet 65/35 illite/ quartz gouge, but with near-neutral to slightly velocityweakening behaviour at $350^{\circ} \mathrm{C}$ instead of velocityweakening.

2. No three-regime slip stability behaviour is observed for $65 / 35$ illite/quartz gouge when deformed dry, yielding near neutral $(a-b)$ values.

3. Though ideally additional experiments on wet illite and dry illite/quartz should be conducted at a wider range of temperatures, the current data suggest that the three-regime slip stability behaviour with velocity-weakening at intermediate temperature of wet illite/quartz gouges is critically dependent on water-assisted, thermally activated deformation of quartz. This is consistent with the microphysical model previously put forward by Den Hartog and
Spiers (2014), in which the velocity-weakening behaviour of wet illite/quartz mixtures was interpreted to be the result of deformation of the illite/quartz mixtures controlled by a competition between shearinduced dilation and compaction involving thermally activated quartz deformation through pressure solution.

4. The similarity between the three regimes of $(a-b)$ behaviour versus temperature seen in experiments, predicted by the model, and implied by the sequence of aseismic-seismic-aseismic behaviour on natural metapelite-dominated megathrusts, suggests that seismogenesis is caused by a brittle-ductile transition process, i.e. it occurs under conditions where the creep process is fast enough to moderate 'brittle' dilatation to remain at subcritical porosity values but too slow to allow ductile shear of the clast phase.

\section{Additional file}

Additional file 1: Ring shear machine used in the present study. (a) Rotary shear drive system and pressure vessel mounted inside the Instron loading frame used to apply normal stress to the sample. (b) Semi-schematic cross section of the pressure vessel. (c) Semi-schematic cross section of the sample assembly. $\sigma_{n}^{\text {eff }}=$ effective normal stress (after Den Hartog et al. 2012a).

\section{Competing interests}

The authors declare that they have no competing interests.

\section{Authors' contributions}

$\mathrm{SdH}$ carried out the experiments and drafted the manuscript. CS participated in the design of the study and helped to draft the manuscript. DS helped to draft the manuscript. All authors read and approved the final manuscript.

\section{Acknowledgements}

We thank the editors for the invitation to contribute to this special issue. Pieter Bertier kindly provided the illite gouge. Gert Kastelein, Thony van der Gon Netscher, Eimert de Graaff and Peter van Krieken provided technical assistance. We thank two anonymous reviewers for their helpful comments.

Received: 11 February 2014 Accepted: 18 July 2014

Published: 28 July 2014

\section{References}

Blanpied ML, Marone CJ, Lockner DA, Byerlee JD, King DP (1998) Quantitative measure of the variation in fault rheology due to fluid-rock interactions. J Geophys Res 103(B5):9691-9712. doi:10.1029/98jb00162

Chester FM, Higgs NG (1992) Multimechanism friction constitutive model for ultrafine quartz gouge at hypocentral conditions. J Geophys Res 97(B2):1859-1870. doi:10.1029/91jb02349

Den Hartog SAM, Niemeijer AR, Spiers CJ (2012a) New constraints on megathrust slip stability under subduction zone P-T conditions. Earth Planet Sci Lett 353-354:240-252. doi:10.1016/j.epsl.2012.08.022

Den Hartog SAM, Niemeijer AR, Spiers CJ (2013) Friction on subduction megathrust faults: beyond the illite-muscovite transition. Earth Planet Sci Lett 373:8-19. doi:10.1016/j.epsl.2013.04.036

Den Hartog SAM, Peach CJ, De Winter DAM, Spiers CJ, Shimamoto T (2012b) Frictional properties of megathrust fault gouges at low sliding velocities: new data on effects of normal stress and temperature. J Struct Geol 38:156-171. doi:10.1016/j.jsg.2011.12.001

Den Hartog SAM, Spiers CJ (2013) Influence of subduction zone conditions and gouge composition on frictional slip stability of megathrust faults. Tectonophysics 600:75-90. doi:10.1016/j.tecto.2012.11.006 
Den Hartog SAM, Spiers CJ (2014) A microphysical model for fault gouge friction applied to subduction megathrusts. J Geophys Res 119(2):1510-1529. doi: $10.1002 / 2013 j b 010580$

Dieterich JH (1978) Time-dependent friction and the mechanics of stick-slip. Pure Appl Geophys 116:790-806

Dieterich JH (1979) Modeling of rock friction 1. Experimental results and constitutive equations. J Geophys Res 84(B5):2161-2168

Folk RL (1962) Petrography and origin of the Silurian Rochester and McKenzie Shales, Morgan County, West Virginia. J Sediment Petrol 32(3):539-578

Gualtieri A, Ferrari S (2006) Kinetics of illite dehydroxylation. Phys Chem Minerals 33(7):490-501. doi:10.1007/s00269-006-0092-z

Hirth G, Tullis J (1994) The brittle-plastic transition in experimentally deformed quartz aggregates. J Geophys Res 99(B6):11731-11747. doi:10.1029/93jb02873

Hyndman RD, Yamano M, Oleskevich DA (1997) The seismogenic zone of subduction thrust faults. Isl Arc 6(3):244-260. doi:10.1111/j.1440-1738.1997. tb00175.x

Ikari MJ, Saffer DM (2011) Comparison of frictional strength and velocity dependence between fault zones in the Nankai accretionary complex. Geochem Geophy Geosy 12:Q0AD11. doi:10.1029/2010gc003442

Ikari MJ, Saffer DM, Marone C (2009a) Frictional and hydrologic properties of a major splay fault system, Nankai subduction zone. Geophys Res Lett 36: L20313. doi:10.1029/2009gl040009

Ikari MJ, Saffer DM, Marone C (2009b) Frictional and hydrologic properties of clay-rich fault gouge. J Geophys Res 114:B05409. doi:10.1029/2008JB006089

Ito Y, Obara K (2006) Very low frequency earthquakes within accretionary prisms are very low stress-drop earthquakes. Geophys Res Lett 33:L09302. doi:10.1029/2006GL025883

Lemmon EW, Huber ML, McLinden MO (2010) NIST standard reference database 23: reference fluid thermodynamic and transport properties-REFPROP, Version 9.0. National Institute of Standards and Technology, standard reference data program, Gaithersburg.

Mariani E, Brodie KH, Rutter EH (2006) Experimental deformation of muscovite shear zones at high temperatures under hydrothermal conditions and the strength of phyllosilicate-bearing faults in nature. J Struct Geol 28(9):1569-1587

Marone C (1998) Laboratory-derived friction laws and their application to seismic faulting. Annu Rev Earth Planet Sci 26:643-696. doi:10.1146/annurev. earth.26.1.643

Meunier A, Velde B (2004) Illite. Springer-Verlag, Berlin

Moore DE, Lockner DA (2008) Talc friction in the temperature range $25^{\circ}-400^{\circ} \mathrm{C}$ : relevance for fault-zone weakening. Tectonophysics 449(1-4):120-132. doi:10.1016/.tecto.2007.11.039

Moore DE, Summers R, Byerlee JD (1989) Sliding behavior and deformation textures of heated illite gouge. J Struct Geol 11(3):329-342. doi:10.1016/0191-8141(89)90072-2

Moore JC (1989) Tectonics and hydrogeology of accretionary prisms: role of the décollement zone. J Struct Geol 11(1-2):95-106

Morrow CA, Moore DE, Lockner DA (2000) The effect of mineral bond strength and adsorbed water on fault gouge frictional strength. Geophys Res Lett 27(6):815-818

Niemeijer AR, Spiers CJ (2007) A microphysical model for strong velocity weakening in phyllosilicate-bearing fault gouges. J Geophys Res 112:B10405. doi:10.1029/2007JB005008

Niemeijer AR, Spiers CJ, Peach CJ (2008) Frictional behaviour of simulated quartz fault gouges under hydrothermal conditions: results from ultra-high strain rotary shear experiments. Tectonophysics 460:288-303

Ruina A (1983) Slip instability and state variable friction laws. J Geophys Res 88 (B12):10359-10370

Rutter EH, Brodie KH (2004) Experimental intracrystalline plastic flow in hotpressed synthetic quartzite prepared from Brazilian quartz crystals. J Struct Geol 26(2):259-270

Saffer DM, Lockner DA, McKiernan A (2012) Effects of smectite to illite transformation on the frictional strength and sliding stability of intact marine mudstones. Geophys Res Lett 39(11):L11304. doi:10.1029/2012gl051761

Scholz CH (1998) Earthquakes and friction laws. Nature 391:37-42. doi:10.1038/34097

Shipboard Scientific Party (2001) Leg 190 summary. In: Moore GF, Taira A, Klaus A (ed) Proceedings of the ocean drilling program, initial reports, vol 190. Ocean Drilling Program, College Station, pp 1-87. doi:10.2973/odp.proc ir.190.101.2001
Shipboard Scientific Party (2003) Leg 205 summary. In: Morris JD, Villinger HW, Klaus A (ed) Proceedings of the ocean drilling program, initial reports, vol 205. Ocean Drilling Program, College Station, TX, pp 1-75. doi:10.2973/odp. proc.ir.205.2003

Steurer JF, Underwood MB (2003) Clay mineralogy of mudstones from the Nankai Trough reference sites 1173 and 1177 and frontal accretionary prism site 1174. In: Mikada H, Moore GF, Taira A, Becker K, Moore JC, Klaus A (ed) Proceedings of the ocean drilling program, scientific results, vol 190/196. Ocean Drilling Program College Station, TX, pp 1-37. doi:10.2973/odp.proc. Sr.190196.211.2003

Tembe S, Lockner DA, Wong T-F (2010) Effect of clay content and mineralogy on frictional sliding behavior of simulated gouges: binary and ternary mixtures of quartz, illite and montmorillonite. J Geophys Res 115:B03416. doi:10.1029/2009JB006383

Underwood MB (2007) Sediment inputs to subduction zones. In: Dixon TH, Moore JC (ed) The seismogenic zone of subduction thrust faults. Columbia University Press, New York, pp 42-85

Underwood MB, Deng X (1997) Clay mineralogy and clay geochemistry in the vicinity of the décollement zone, northern Barbados Ridge. In: Shipley TH, Ogawa Y, Blum P, Bahr JM (ed) Proceedings of the ocean drilling program, scientific results, vol 156. Ocean Drilling program, College Station, TX, pp 3-30

Van Diggelen EWE, De Bresser JHP, Peach CJ, Spiers CJ (2010) High shear strain behaviour of synthetic muscovite fault gouges under hydrothermal conditions. J Struct Geol 32:1685-1700. doi:10.1016/j.jsg.2009.08.020

Wagner W, Pruss A (2002) The IAPWS formulation 1995 for the thermodynamic properties of ordinary water substance for general and scientific use. J Phys Chem Ref Data 31:387-535

\section{doi:10.1186/1880-5981-66-78}

Cite this article as: den Hartog et al.: The roles of quartz and water in controlling unstable slip in phyllosilicate-rich megathrust fault gouges. Earth, Planets and Space 2014 66:78.

\section{Submit your manuscript to a SpringerOpen ${ }^{\circ}$ journal and benefit from:}

- Convenient online submission

- Rigorous peer review

- Immediate publication on acceptance

- Open access: articles freely available online

- High visibility within the field

- Retaining the copyright to your article

Submit your next manuscript at $\boldsymbol{~ s p r i n g e r o p e n . c o m ~}$ 